\title{
Paracoccidioides brasiliensis infection in dogs from Western Brazilian Amazon ${ }^{1}$
}

INDEX TERMS: Paracoccidioides brasiliensis, paracoccidioidomycosis, epidemiology, Amazon, dogs.

RESUMO.- [Infecção por Paracoccidioides brasiliensis em cães da Amazônia Ocidental Brasileira.] 0 objetivo deste estudo foi avaliar a infecção por Paracoccidioides brasiliensis em cães urbanos do município de Monte Negro, Rondônia, Amazônia Ocidental Brasileira. As amostras de soro $(n=126)$ foram analisadas por meio dos testes de ELISA indireto e imunodifusão utilizando gp43 de $P$. brasiliensis e exoantígeno como antígenos, respectivamente. Uma positividade de $54,8 \%$ foi observada apé isso mesmoenas no teste de ELISA e nenhuma diferença estatística foi observada na soroprevalência em relação ao sexo ou à idade. Este é o primeiro estudo epidemiológico de paracoc-

\footnotetext{
${ }^{1}$ Received on February 1, 2012.

Accepted for publication on March 14, 2012.

${ }^{2}$ Departamento de Ciências Patológicas, Universidade Estadual de Londrina (UEL), Rodovovia Celso Garcia Cid, PR $445 \mathrm{Km} 380$, Campus Universitário, Caixa Postal 6001, Londrina, PR 86051-980, Brazil. *Corresponding author: marioono@uel.br

${ }^{3}$ Departamento de Medicina Veterinária Preventiva e Saúde Animal, Faculdade de Medicina Veterinária e Zootecnia, Universidade de São Paulo (USP), Av. Prof. Dr. Orlando Marques de Paiva 87, Cidade Universitária, São Paulo, SP 05508-270, Brazil.

${ }^{4}$ Instituto de Ciências Biomédicas, USP, São Paulo, SP 05508-900.

${ }^{5}$ Departamento de Medicina Veterinária Preventiva, UEL, Londrina, PR.

${ }^{6}$ Disciplina de Biologia Celular, Universidade Federal de São Paulo, Rua Botucatu862, São Paulo, SP 04023-062.
}

cidioidomicose realizado com cães da Amazônia Ocidental Brasileira. A alta positividade de infecção por P. brasiliensis observada neste estudo sugere que os veterinários devem estar atentos para detectar a doença natural em cães de áreas endêmicas para paracoccidioidomicose.

TERMOS DE INDEXAÇÃO: Paracoccidioides brasiliensis, paracoccidioidomicose, epidemiologia, Amazônia, canino.

\section{INTRODUCTION}

Paracoccidioides brasiliensis is the ethiological agent of paracoccidioidomycosis, a systemic granulomatous mycosis that mainly affects rural workers living in Latin American countries (Brummer et al. 1993). The infection occurs by inhalation of fungus propagules while working with the soil, the probable habitat of $P$. brasiliensis (Negroni 1966, Albornoz 1971, Restrepo, 1985, Silva-Vergara et al. 1998, Terçarioli et al. 2007).

Epidemiological studies have shown that paracoccidioidomycosis occurs in several species of domestic and wild animals such as dogs (Mós \& Fava-Netto 1974, Ono et al. 2001, Silveira et al. 2006, Canteros et al. 2010, Fontana et al. 2010), cows (Silveira et al. 2008), horses (Conti Diaz et al. 1972, Costa \& Fava-Netto 1978, Corte et al. 2009), armadillos (Fernandes et al. 2004), sheep (Costa \& Fava-Netto 1978, Oliveira et al. 2011), monkeys (Corte et al. 2007), 
guinea pigs, raccoons, grisons, porcupine (Richini-Pereira et al. 2008) and chickens (Gonçalves et al. 2011). The fungus was also isolated from armadillos (Naiff et al. 1986, Bagagli et al. 1998, Corredor et al. 1999, Silva-Vergara et al. 2000) penguin faeces (Gezuele 1989), and recently, natural paracoccidioidomycosis was reported in two dogs (Ricci et al. 2004, Farias et al. 2011), a cat (Gonzalez et al. 2010) and a two-toed sloth (Trejo-Chávez et al. 2010).

The first experimental study with paracoccidioidomycosis in dogs was reported in 1911 (Pereira \& Vianna 1911). Several decades later the natural infection by $P$. brasiliensis was reported in dogs from São Paulo (74.3-78.2\%), Paraná (14.8-89.5\%), Mato Grosso do Sul (67.8\%), Minas Gerais (53.7\%), in Brazil (Mós \& Fava-Netto 1974, Ono et al. 2001, Silveira et al. 2006, Fontana et al. 2010) and Argentina (2.2\%) (Canteros et al. 2010).

Taking into account that $P$. brasiliensis probably lives in soil as a saprobe, the dog's habit of sniffing and digging the soil could expose the animal to P. brasiliensis infection (Ono et al. 2001).

The objective of this study was to evaluate the infection by $P$. brasiliensis in dogs from Monte Negro, a municipality located in the Western Amazonian Region, Brazil.

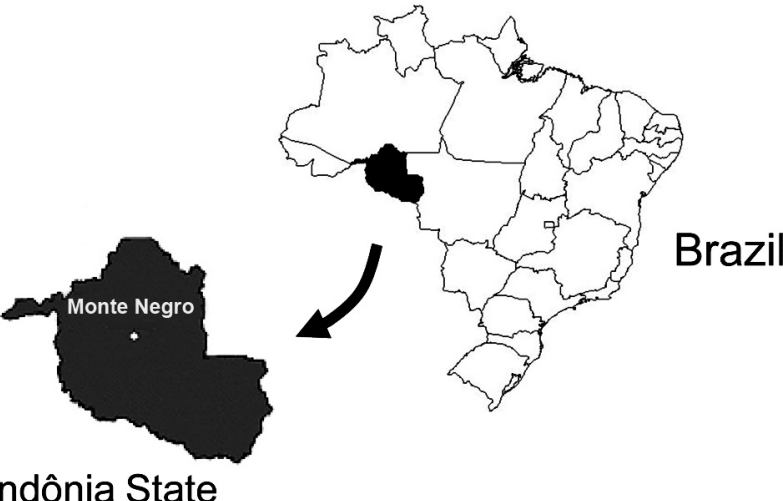

\section{Rondônia State}

Fig.1. Map showing the municipality of Monte Negro in the state of Rondônia, Brazil.

\section{MATERIALS AND METHODS}

\section{Study area}

The municipality of Monte Negro is located in Rondônia State, in the Western Region of the Brazilian Amazon $\left(10^{\circ} 18^{\prime}\right.$ S, 63 $63^{\circ} 4^{\prime}$ W). The climate is hot and humid $\left(25-29^{\circ} \mathrm{C}\right)$ with two hallmark seasons, the rainy season (October to April $1440 \mathrm{~mm}$ mean rainfall) and the dry season (June to August, $559 \mathrm{~mm}$ mean rainfall).

\section{Animals}

Blood samples were collected by venipuncture from 126 dogs (72 males and 54 females) living in the urban area of Monte Negro Municipality and at least one animal was sampled in the 85 blocks with dogs. The animals were classified as puppy $(<1$ year), young (1-2 years) and adult ( $>2$ years).

\section{Paracoccidioides brasiliensis antigens}

Exoantigen.The exoantigen was obtained as previously described (Camargo et al. 1988), using the P. brasiliensis isolate B-339.
Gp43 antigen. The gp43 antigen was purified from $P$. brasiliensis exoantigen by immunoaffinity chromatography as previously described (Puccia and Travassos 1991) and the protein concentration was determined by the Bradford method using BSA as standard (Bradford 1976).

\section{Immunodiffusion test}

The serum samples from $P$. brasiliensis immunized animals were analyzed by the immunodiffusion test as previously described (Camargo et al. 1988) using P. brasiliensis exoantigen as reagent.

\section{ELISA with gp43}

The 126 serum samples from urban dogs were analyzed by ELISA using gp43 as antigen. Flat bottom Microtitre polystyrene plates (Costar Corporation, Corning, NY,USA) were coated at $4^{\circ} \mathrm{C}$ overnight with 250 ng well of gp 43 in carbonate buffer, $\mathrm{pH}$ 9.6. After washing with PBS-T (PBS with Tween 20) the wells were blocked with $2 \%$ skim milk in PBS for 1 hour at $37^{\circ} \mathrm{C}$. After washing with PBS-T the serum samples, diluted 1:100 in PBS-1\% skim milk were incubated at $25^{\circ} \mathrm{C}$ for 1 hour. The plates were washed with PBS-T and the anti-dog IgG-peroxidase conjugate (Sigma, St Louis, MO, USA) was added followed by incubation for 1 hour at $37^{\circ} \mathrm{C}$. After washing with PBS-T the substrate-chromogen solution $\left(\mathrm{H}_{2} \mathrm{O}_{2} / \mathrm{TMB}\right)$ was added. The reaction was stopped by adding $\mathrm{H}_{2} \mathrm{SO}_{4} 4 \mathrm{~N}(50 \mu \mathrm{l} /$ well). The absorbance $(450 \mathrm{~nm})$ was analyzed in a Microplate Reader (Biotek Instruments Inc., Winooski, VT, USA). All serum samples were analyzed twice. The positive and negative controls were a serum sample from a dog immunized with $P$. brasiliensis and a pool of sera from young urban dogs, respectively. Sera with two-fold or more the absorbance of the negative control were considered positive.

\section{Statistical analysis}

The statistical analysis was performed with the program EpiInfo® 6.0 (Dean et al. 1994) using the chi-square test and Yates' qui-square test. The difference was considered significant when $\mathrm{P}$ was less than 0.05 .

\section{RESULTS}

A $54.8 \%$ positivity was observed in the ELISA test although no reactivity was detected by the immunodiffusion test and the positivity rates observed in males (52.7\%) and females (57.6\%) were not significantly different (Table 1 ).

No statistical difference was observed in relation to age in puppies $(37.5 \%)$ compared to adults (57\%) and young animals (58.8\%) (Table 1).

Table 1. Reactivity to Paracoccidioides brasiliensis in 126 serum samples from urban dogs evaluated by ELISA and Immunodiffusion (ID), according to sex and age

\begin{tabular}{lcc}
\hline & \multicolumn{2}{c}{ Positivity n (\%) } \\
\cline { 2 - 3 } Male & ELISA & ID \\
Female & $39(52.7)$ & $0(0)$ \\
Adult & $50(57.6)$ & $0(0)$ \\
Young & $10(58.8)$ & $0(0)$ \\
Puppy & $6(37.5)$ & $0(0)$ \\
TOTAL & $69(54.8)$ & $0(0)$ \\
& & $0(0)$
\end{tabular}




\section{DISCUSSION}

Infection by Paracoccidioides brasiliensis of domestic and wild animals has been observed in epidemiological studies using immunological and molecular methods. In this study the infection by $P$. brasiliensis was evaluated in dogs from the Brazilian Western Amazonian region.

The positivity observed by ELISA in this study is similar to other seroepidemiological studies of paracoccidioidomycosis in urban dogs from Paraná (Ono et al. 2001) and Minas Gerais (Fontana et al. 2010) Brazilian states, which reported positivity rates of $51.5 \%$ and $53.7 \%$, respectively.

The immunodiffusion with exoantigen is the test of choice for diagnosis of paracoccidioidomycosis in humans (Camargo 2008). The lack of reactivity observed in the immunodiffusion test probably is due its lower sensitivity when compared with ELISA and suggests that dogs were infected by $P$. brasiliensis but without disease as observed in other seroepidemiological studies (Ono et al. 2001, Fontana et al. 2010). Individuals living in paracoccidioidomycosis endemic areas are frequently infected by $P$. brasiliensis although most of them will not develop the disease (Franco 1986).

No significant difference was observed in relation to sex as observed in other seroepidemiological studies carried out by our group to evaluate paracoccidioiomycosis infection in dogs, monkeys and chickens (Ono et al. 2001, Silveira et al. 2006, Corte et al. 2007, Oliveira et al. 2011).

Although no statistical difference was observed in relation to age a trend of lower seroprevalence was observed in puppies. In another study carried out by our group to evaluate infection by $P$. brasiliensis in urban dogs from Mato Grosso do Sul, a significantly lower positivity was observed in dogs under one year old (Silveira et al. 2006). In studies on experimental paracoccidioidomycosis in dogs, puppies were more susceptible to developing paracocccidioidomycosis than adults (Ono et al. 2003, Eisele et al. 2004).

This is the first study of $P$. brasiliensis infection in dogs from the Western Brazilian Amazon. The higher positivity rates of $P$. brasiliensis infection observed in this study reinforces that dog is a useful and sensitive epidemiological marker of paracoccidioidomycosis and suggest that veterinarians must be alert to detect new cases of natural disease in dogs living in paracoccidioidomycosis endemic areas.

Acknowledgements.- To CNPq, CAPES and the Araucária Foundation, for the financial support of the study.

\section{REFERENCES}

Albornoz M.B. 1971. Isolation of Paracoccidioides brasiliensis from rural soil in Venezuela. Sabouraudia 9:248-253.

Bagagli E., Sano A., Coelho K.I., Alquati S., Miyaji M., Camargo Z.P., Gomes G.M., Franco M. \& Montenegro M.R. 1998. Isolation of Paracoccidioides brasiliensis from armadillos (Dasypus novemcinctus) captured in an area of paracoccidioidomycosis. Am. J. Trop. Med. Hyg. 58:505-512.

Bradford M.M. 1976. A rapid and sensitive method for the quantitation of microgram quantities of protein utilizing the principle of protein-dye binding. Analyt.. Biochem. 72:248-254.

Brummer E., Castaneda E. \& Restrepo A. 1993. Paracoccidioidomycosis: An update. Clin. Microbiol. Rev. 6:89-117.

Camargo Z.P. 2008. Serology of paracoccidioidomycosis. Mycopathologia 165:289-302.
Camargo Z.P., Unterkircher C.S., Campoy S.P. \& Travassos L.R. 1988. Production of Paracoccidioides brasiliensis exoantigens for immunodiffusion tests. J. Clin. Microbiol. 26:2147-2151.

Canteros C.E., Madariaga M.J., Lee W., Rivas M.C., Davel G. \& Iachini R. 2010. Endemic fungal pathogens in a rural setting of Argentina: Seroepidemiological study in dogs. Revta Iberoam. Micol. 27:14-19.

Conti-Diaz I.A., Alvarez B.J., Gezuele E., Gonzalez M.H., Duarte J. \& Falcon J. 1972. Intradermal reaction survey with paracoccidioidin and histoplasmin in horses. Rev. Inst. Med. Trop., São Paulo, 14:372-376.

Corredor G.G., Castaño J.H., Peralta L.A., Díez S., Arango M., McEwen J. \& Restrepo A. 1999. Isolation of Paracoccidioides brasiliensis from the nine-banded armadillo Dasypus novemcinctus, in an endemic area for paracoccidioidomycosis in Colombia. Revta Iberoam. Micol. 16:216-220.

Corte A.C., Svoboda W.K., Navarro I.T., Freire R.L., Malanski L.S., Shiozawa M.M., Ludwig G., Aguiar L.M., Passos F.C., Maron A., Camargo Z.P., Itano E.N. \& Ono M.A. 2007. Paracoccidioidomycosis in wild monkeys from Paraná State, Brazil. Mycopathologia 164:225-228.

Corte A.C., Itano E.N., Freire R.L., Camargo Z.P. \& Ono M.A. 2009. Detection of antibodies to Paracoccidioides brasiliensis in horses from northern Region of Paraná State. Semina. Ciênc. Agrárias 30:441-446.

Costa E.O. \& Fava-Netto C. 1978. Contribution to the epidemiology of paracoccidioidomycosis and histoplasmosis in the State of São Paulo, Brazil: Paracoccidioidin and histoplasmin intradermic tests in domestic animals. Sabouraudia 16:93-101.

Dean A.G., Dean J.A., Coulombier D., Brendel K.A., Smith D.C., Burton A.H., Dicker R.C., Sullivan K., Fagan R.F. \& Arner T.G. 1994. Epi Info, Version 6: A word processing database, and statistic program for epidemiology on microcomputers. Center for Diseases Control and Prevention, Atlanta.

Eisele R.C., Juliani L.C., Belitardo D.R., Itano E.N., Estevão D., Bracarense A.P.F.R.L., Camargo Z.P. \& Ono M.A. 2004. Immune response in dogs experimentally infected with Paracoccidioides brasiliensis. Med. Mycol. 42:549-553.

Farias M.R., Condas L.A.Z., Ribeiro M.G., Bosco S.M., Muro M.D., Werner J., Theodoro R.C., Bagagli E., Marques S.A. \& Franco M. 2011. Paracoccidioidomycosis in a dog: Case report of generalized lymphadenomegaly. Mycopathologia 172:147-152.

Fernandes G.F., Deps P., Tomimori-Yamashita J. \& Camargo Z.P. 2004. IgM and IgG antibody response to Paracoccidioides brasiliensis in naturally infected wild armadillos (Dasypus novemcinctus). Med. Mycol. 42:363368.

Fontana F.F., Santos C.T.B., Esteves F.M., Rocha A., Fernandes G.F., Amaral C.C., Domingues M.A., Camargo Z.P. \& Silva-Vergara M.L. 2010. Seroepidemiological survey of paracoccidioidomycosis Infection among urban and rural dogs from Uberaba, Minas Gerais, Brazil. Mycopathologia 169:159-165.

Franco M. 1987. Host-parasite relationships in paracoccidioidomycosis. J. Med. Vet. Mycol. 25:5-18.

Gezuele E. 1989. Aislamiento de Paracoccidioides brasiliensis de heces de pinguino de la Antardida. IV Encuentro Internacional sobre Paracoccidioidomicosis, Caracas, Venezuela. Instituto Venezuelano de Investigaciones Cientificas (IVIC), Abstract B2.

Gonzalez J.F., Montiel N.A. \& Maass R.L. 2010. First report on the diagnosis and treatment of encephalic and urinary paracoccidioidomycosis in a cat. J. Feline Med. Surg. 12:659-662.

Mós E.N. \& Fava-Netto C. 1974. Contribuição ao estudo da paracoccidoidomicose. I -Possível papel dos cães: Estudo sorológico e anatomo-patológico. Revta Inst. Med. Trop., São Paulo, 16:154-159.

Naiff R.D., Ferreira L.C.L., Barret T.V., Naif M.F. \& Arias J.R. 1986. Paracoccidioidomicose enzoótica em tatus (Dasypus novemcinctus) no estado do Pará. Revta Inst. Med. Trop., São Paulo, 28:19-27.

Negroni P. 1966. El Paracoccidioides brasiliensis vive saprofiticamente en el suelo argentino. Prensa Méd. Argent. 53:2831-2832.

Oliveira G.G., Silveira L.H., Itano E.N., Soares R.M., Freire R.L., Watanabe M.A.E., Camargo Z.P. \& Ono M.A. 2011. Serological evidence of Paracoccidioides brasiliensis infection in chickens from Paraná and Mato Grosso do Sul States, Brazil. Mycopathologia 171:197-202. 
Oliveira G.G., Navarro I.T., Freire R.L. Belitardo D.R., Silveira L.H., Camargo Z.P., Itano E.N. \& Ono M.A. 2012. Serological survey of Paracoccidioidomycosis in sheep. Mycopathologia 173:63-68.

Ono M.A., Bracarense A.P.F.R.L., Morais H.S.A., Trapp S.M., Belitardo D.R. \& Camargo Z.P. 2001. Canine paracoccidioidomycosis: A seroepidemiologic study. Med. Mycol. 39:277-282.

Ono M.A., Kishima M.O., Itano E.N., Bracarense A.P.F.R.L. \& Camargo Z.P. 2003. Experimental paracoccidioidomycosis in dogs. Med. Mycol. 41: 265-268.

Pereira M. \& Viana G. 1911. A propósito de um caso de blastomicose (Pyohemia blastomycotica). Arq. Bras. Med. 1:63-83.

Puccia R. \& Travassos L.R. 1991. The 43-kDa glycoprotein from the human pathogen Paracoccidioides brasiliensis and its deglycosylated form: excretion and susceptibility to proteolysis. Arch. Biochem. Biophys. 289:298-302.

Restrepo A. 1985. The ecology of Paracoccidioides brasiliensis: A puzzle still unsolved. Sabouraudia 23:323-334.

Ricci G., Mota F.T., Wakamatsu A., Serafim R.C., Borra R.C. \& Franco M. 2004. Canine paracoccidioidomycosis. Med. Mycol. 42:379-383.

Richini-Pereira V.B., Bosco S.M., Griese J., Theodoro R.C., Macoris S.A., Silva R.J., Barrozo L., Tavares P.M., Zancopé-Oliveira R.M. \& Bagagli E. 2008. Molecular detection of Paracoccidioides brasiliensis in road-killed wild animals. Med. Mycol. 46:35-40.
Silva-Vergara M.L., Martinez R., Chadu A., Madeira M., Freitas-Silva G. \& Maffei C.M.L. 1998. Isolation of Paracoccidioides brasiliensis strain from the soil of a coffee plantation in Ibiá, State of Minas Gerais, Brazil. Med. Mycol. 36:37-42.

Silva-Vergara M.L., Martinez R., Camargo Z.P., Malta M.H., Maffei C.M. \& Chadu J.B. 2000. Isolation of Paracoccidioides brasiliensis from armadillos (Dasypus novemcinctus) in an area where the fungus was recently isolated from soil. Med. Mycol. 38:193-199.

Silveira L.H., Domingos I.H., Kouchi K., Itano E.N., Silva E.A., Landgraf V.O., Werneck S.M., Camargo Z.P. \& Ono M.A. 2006. Serological detection of antibodies against Paracoccidioides brasiliensis in dogs with leishmaniasis. Mycopathologia 162:325-329.

Silveira L.H., Paes R.C.S., Medeiros E.V., Itano E.N., Camargo Z.P. \& Ono M.A. 2008. Occurrence of antibodies to Paracoccidioides brasiliensis in dairy cattle from Mato Grosso do Sul, Brazil. Mycopathologia 165:367-371.

Terçarioli G.R., Bagagli E., Reis G.M., Theodoro R.C., Bosco S.M.G., Macoris S.A.G. \& Pereira V.B.R. 2007. Ecological study of Paracoccidioides brasiliensis in soil: growth ability, conidia production and molecular detection. BMC Microbiol. 7:92.

Trejo-Chávez A., Ramírez-Romero R., Ancer-Rodríguez J., Nevárez-Garza A.M. \& Ródríguez-Tovar L.E. 2011. Disseminated Paracoccidioidomycosis in a Southern two-toed sloth (Choloepus didactylus). J. Comp. Pathol. 144:231-234. 